\title{
CYBERBULLYING USE ON TEENAGE ARTISTS AND ITS IMPLICATIONS ON INCREASING AWARENESS OF BULLYING
}

\author{
Sheira Ayu Indrayani dan Citra Aulia Johansari \\ Universitas Pendidikan Indonesia \\ email: sheira.indrayani@upi.edu
}

\begin{abstract}
Cyberbullying in the comment section on the social media tends to be a common phenomenon nowadays. Negative comments lead to bullying being the dark side of the social media, the Instagram in particular, which is clearly visible in the comment section; moreover, in uploaded photos of teen artists that have many followers on their Instagram. This study has three objectives: first, obtaining the lexical meaning of cyberbullying from negative comments in the comment section of some Indonesian teen artists uploaded photos on their personal Instagram; second, describing the phenomenon of cyberbullying; third, providing implications for increasing awareness of bullying. Purposive sampling was used to collect data by reading every single comment to get negative comments in the comment section. Semantic components were used to have the lexical meaning of cyberbullying, whereupon the result was classified into Willard (2007)'s cyberbullying types. The result reveals three things. First, the lexical component of cyberbullying consists of comments that are negative, rude, and indecent. Second, there are two types of cyberbullying: harassment and cyberstalking. Third, the implication of this study is that tangible, sustainable, and comprehensive character building and sex education at all levels of society could be a solution to reduce cyberbullying.
\end{abstract}

Keywords:cyberbullying, semantic components, social media

\section{PEMAKNAAN CYBERBULLYING PADA ARTIS REMAJA SERTA IMPLIKASINYA TERHADAP PENINGKATAN KESADARAN AKAN PERUNDUNGAN}

\begin{abstract}
Abstrak
Cyberbullying pada kolom komentar di media sosial cenderung menjadi fenomena yang biasa terjadi kini. Komentar negatif mengarah kepada perundungan menjadi sisi kelam media sosial, Instagram khususnya, yang terlihat jelas pada kolom komentar. Terlebih, pada berbagai unggahan foto para artis remaja dimana mereka memiliki banyak pengikut di laman Instagramnya. Penelitian ini memiliki tiga tujuan, yaiu untuk memperoleh makna leksikal cyberbullying dari komentar-komentar negatif pada kolom komentar beberapa foto artis remaja Indonesia yang diunggah di Instagram pribadi mereka; untuk menggambarkan fenomena cyberbullying yang terjadi; dan untuk memberikan implikasi terhadap peningkatan kesadaran akan perundungan berdasarkan temuan. Pur-
\end{abstract}


posive sampling digunakan untuk mengumpulkan datayaitudengan membaca satu per satu komentar guna menemukan komentar-komentar negatif pada kolom komentar artis-artis remaja. Analisis komponen makna digunakan untuk mengetahui makna leksikal $c y$ berbullying, hasilnya diklasifikasikan ke dalam jenis cyberbullying Willard (2007). Hasil penelitian menemukan tiga hal. Pertama, komponen makna leksikal cyberbullyingyang ditemukan adalahasusila, tidak baik, dan umpatan. Kedua, ada dua jenis cyberbullying yang terjadi:harassment dan flaming. Ketiga, implikasi dari penelitian ini adalah adanya pendidikan karakter dan pendidikan seks yang nyata, berkesinambungan, dan menyeluruh di seluruh lapisan masyarakat menjadi solusi untuk mengurangi cyberbullying.

Kata kunci: cyberbullying, komponen makna, media sosial

\section{PENDAHULUAN}

Perkembangan teknologi informasi, internet, dan media sosial memberikan dampak perubahan kepada perilaku manusia dalam bersosial dan berkomunikasi (Rifauddin, 2016). Namun, tidak semua orang berkomunikasi dan bersosialisasi dengan benar ketika menggunakan teknologi. Remaja, tanpa pengawasan orang tua, seringkali bersinggungan langsung dengan cyberbullying. Terlebih, penggunaan gawai, dalam lingkup sosial, menjadikan penyimpangan komunikasi ini semakin terasa dekat dengan mereka. Singkatnya, kemajuan media komunikasi belum tentu sejalan dengan sikap positif penggunanya.

Indonesia memiliki jumlah pengguna internet yang banyak. Data dari Internet World Stats menunjukkan bahwa pengguna internet di Indonesia pada Desember 2017 adalah 143,260,000 (53.7\%). Benua Asia pada angka 2,023,630,194 (48.7\%) menempati posisi pertama pengguna internet terbanyak di dunia. Salah satu media komunikasi terbaru yang banyak digunakan adalah Instagram. Berdasarkan hasil survei WeAreSocial.net dan Hootsuite pada Juni 2018, Instagram me- miliki jumlah pengguna terbanyak ke tujuh di dunia dan Indonesia menduduki peringkat ketiga, yaitu sebanyak 53 juta pengguna. Data ini menunjukkan bahwa masyarakat, di Indonesia terutama, hidup berdampingan dengan teknologi.

Perkembangan teknologi media sosial membawa dua sisi, yaitu baik dan buruk. Salah satu sisi buruk yang terjadi adalah cyberbullying di media sosial. Cyberbullying adalah kesalahan dari penggunaan teknologi informasi yang merugikan atau menyakiti dan melecehkan orang lain dengan sengaja secara berulang-ulang (Hidajat et.al., 2015). Cyberbullying menimbulkan keadaan di mana korban terus-menerus mendapatkan pesan negatif dari pelaku perundungan melalui internet pada media sosialnya. Sejalan dengan itu, sebanyak 90,4\% responden dalam penelitian O'Dea \& Campbell (2012) menyetujui bahwa $c y$ berbullying adalah hinaan dari seseorang yang tidak dikenal.

Cyberbullying dikatakan sebagai agresi sosial yang dilakukan di internet, yaitu dengan mengirim atau mengunggah materi berbahaya ke internet atau teknologi digital lainnya yang bisa berujung kepada 
tindakan negatif di masyarakat (Willard, 2007). Tindakan cyberbullying semakin sulit untuk dikontrol karena seringkali tidak dilaporkan kejadiannya kepada orang tua atau pihak berwenang. Para korban biasanya tidak melaporkan karena mereka merasa dapat menyelesaikannya sendiri dan adanya ketakutan tidak akan lagi mendapatkan akses internet (Aune, 2009).

Cyberbullying adalah aktivitas yang dekat dengan pelajar dan remaja. Pratiwi (2011) dalam penelitiannya menemukan bahwa terdapat tiga hal yang mendorong remaja melakukan cyberbullying: emosi yang dirasakan, karakteristik kepribadian, dan persepsi terhadap korban. Para remaja memang sangat rawan melakukan cyberbullying dalam penggunaan jejaring sosial karena terpancing rasa keingintahuan yang besar (Maya, 2015). Sartana \& Afriyeni (2017) dalam penelitiannya, melibatkan 157 remaja laki-laki dan 196 remaja perempuan dengan rentang usia 12-15 tahun, menemukan bahwa $78 \%$ responden penelitiannya pernah melihat perundungan maya, $21 \%$ pernah menjadi pelaku, dan $49 \%$ pernah menjadi korban. Fakta ini membuktikan bahwa memang remaja rentan dengan aktivitas cyberbullying.

Fenomena cyberbullying yang menjadi fokus pada penelitian ini adalah komentar-komentar negatif yang ada pada kolom komentar di unggahan foto beberapa artis remaja Indonesia di Instagram masing-masing mereka. Tidak hanya menggambarkan cyberbullying yang terjadi, namun penelitian ini turut memberikan makna leksikal cyberbullying berdasarkan komentar-komentar terpilih dan kemudian memaknainya dengan mengaitkan- nya terhadap implikasi bagi pembaca agar dapat lebih sadar terhadap bentuk cyberbullying yang ada di sekitar mereka dan bagaimana menanggapi fenomena ini. Adapun tujuan penelitian ini adalah untuk: (a) memperoleh makna leksikal cyberbullying dari komentar-komentar negatif pada kolom komentar beberapa foto artis remaja Indonesia yang diunggah di Instagram pribadi mereka; (b) menggambarkan fenomena cyberbullying yang terjadi; dan (c) memberikan implikasi terhadap peningkatan kesadaran akan perundungan berdasarkan temuan.

\section{METODE}

Tujuan penelitian ini adalah menggambarkan fenomena cyberbullying yang terjadi pada lima akun instagram artis remaja Indonesia berinisial AT, AH, CK, BS, dan KR. Penggambaran fenomena tersebut berlandaskan pada makna leksikal kata cyberbullying yang ditentukan dari hasil analisis komponen makna. Penelitian deskriptif kualitatif ini menganalisis 150 tanggapan pada kolom komentar unggahan foto-foto kelima artis tersebut. Pemilihan komentar berdasarkan teknik purposive sampling, yaitu membaca satu per satu komentar pada unggahan-unggahan foto artis-artis tersebut dan memilih komentar untuk dianalisis berdasarkan kebutuhan, yaitu yang bermakna negatif. Komentar-komentar terpilih akan dianalisis menggunakan analisis komponen makna guna mencari makna leksikal dari cyberbullying. Analisis komponen makna atau analisis komponensial bertujuan untuk mendeskripsikan bagaimana sebuah makna kata terbentuk dari berbagai komponen; bisa satu atau lebih (Allan, 2001). 
Berbagai komentar tersebut dikelompokkan berdasarkan jenis cyberbullying Willard (2007) untuk mengetahui jenis yang mana yang paling banyak ditemukan. Klasifikasi yang digunakan adalah sebagai berikut. (a) Flaming: pertengkaran di internet dengan mengirimkan pesan elektronik dengan penuh kekesalan dan bahasa yang kasar. (b) Harassment: Tindakan mengirimkan pesan bersifat menyerang, kasar, dan penghinaan. (c) Denigration: Tindakan merusak reputasi seseorang dengan cara mengirimkan pesan gosip dan menyebarluaskan berita-berita yang diragukan kebenarannya. (d) Impersonation: Tindakan meretas masuk ke akun seseorang, menyamar sebagai orang itu dan mengirim pesan sebagai orang tersebut untuk merusak reputasinya, membuat masalah, atau menyalahgunakan akun tersebut. (e) Outing and trick- nipu seseorang agar mengungkapkan rahasia atau informasi memalukan, yang kemudian pun dibagikan melalui internet. (f) Exclusion: Tindakan yang secara sengaja mengeluarkan seseorang dari sebuah grup daring, seperti mengelompokkan orang berdasarkan daftar pertemanan. (g) Cyberstalking: Tindakan berkesinambungan dalam mengirim pesan ancaman atau sangat mengintimidasi sehingga membuat si penerima pesan merasa dalam bahaya dan takut akan keselamatannya.

Adapun skema peneitian ditunjukkan pada Gambar 1.

\section{HASIL DAN PEMBAHASAN \\ Hasil \\ Komponen Makna}

Hasil analisis mengungkap bahwa makna cyberbullying ditemukan memiliki

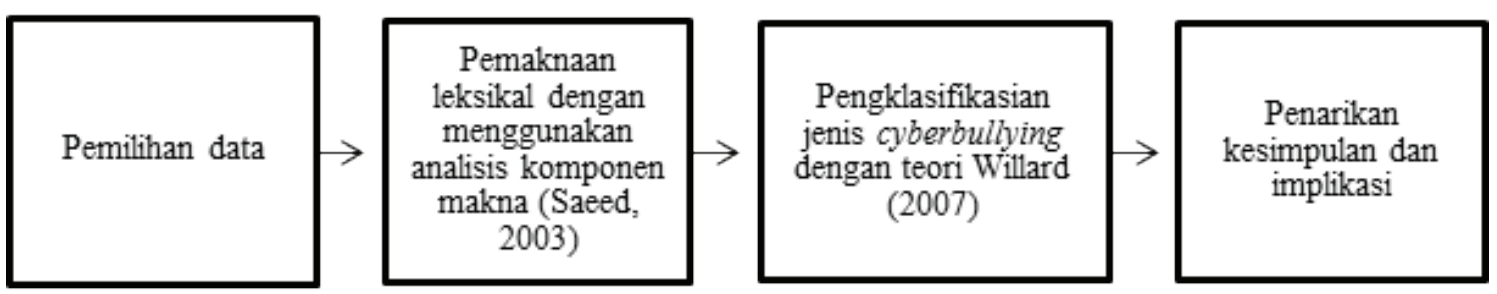

Gambar 1: Skema Penelitian

ery: Tindakan membagikan rahasia seseorang atau mempermalukannya dengan informasi atau gambar melalui internet. Jenis ini juga memasukkan tindakan me- komponen-komponen makna bersifat negatif. Adapun identitas pengirim dan penerima komentar-komentar tersebut disamarkan disajikan pada Tabel 1-7.

Tabel 1: Jumlah Klasifikasi Komponen Makna Pada Komentar Terpilih

\begin{tabular}{ccccccc}
\hline & \multicolumn{7}{c}{ Komponen makna } \\
\cline { 2 - 7 } AT & Fisik & Kasar & Asusila & Umpatan & Tindakan & Tidak baik \\
\cline { 2 - 8 } & 16 & 5 & 30 & 7 & 7 & 30 \\
CK & 19 & 2 & 29 & 16 & 1 & 29 \\
BS & 19 & 5 & 30 & 12 & - & 30 \\
KR & 11 & 21 & 30 & 29 & - & 30 \\
$\sum$ & 16 & 8 & 30 & 22 & 2 & 30 \\
\hline
\end{tabular}


Tabel 2: Contoh Komponen Makna Fisik

\begin{tabular}{lll}
\hline Inisial & Komentar & Komponen Makna \\
\hline AT & Gendut oh gendut.... & $+[$ besar $]$ \\
& & $+[$ perut seakan-akan menggantung] \\
& & $+[$ bunting $]$ \\
AH & Pepeqnya juga cantik & $+[$ pepek $]$ \\
& & $+[$ kemaluan perempuan $]$ \\
& & $+[$ organ tubuh $]$ \\
CK & Enggak sipit. Sekarang sipit & $+[$ tentang mata $]$ \\
& & $+[$ tidak lebar atau bilat $]$ \\
& & $+[$ kecil $]$ \\
BS & Kerempeng badannya & $+[$ sangat kurus $]$ \\
& & $+[$ tulang tampak menonjol $]$ \\
& & $+[$ tentang bentuk badan $]$ \\
KR & susu udah turun & $+[$ payudara $]$ \\
& & $+[$ dada $]$ \\
& & $+[$ organ tubuh $]$ \\
\hline
\end{tabular}

Tabel 3: Contoh Komponen Makna Kasar

\begin{tabular}{lll}
\hline Inisial & Komentar & Komponen Makna \\
\hline AT & Bacot & $+[$ mulut $]$ \\
& & $+[$ banyak omong $]$ \\
& & $+[$ berisik $]$ \\
AH & Kayak lonte anjirr & $+[$ perempuan jalang $]$ \\
& & $+[$ wanita $]$ \\
& & $+[$ tunasusila $]$ \\
CK $\quad$ Idung nya itu loh kayak hidung babi wkwk dah tu & $\underline{\text { Babi }}$ \\
& sok cantik pulak lo babi lo sama kakak mama lo & $+[$ binatang $]$ \\
& yang sok cantik anak haram lo & $+[$ umpatan $]$ \\
& & $+[$ kasar $]$ \\
& & \\
& & Haram \\
& & $+[$ terlarang $]$ \\
& & $+[$ tidak sah $]$ \\
BS & Mau mati ga? & $+[$ tidak boleh $]$ \\
& & $+[$ sudah hilang nyawa $]$ \\
& & $+[$ tidak hidup lagi $]$ \\
KR & Lubang idung kegedean woy kontrol gblk & $+[$ tidak pernah hidup $]$ \\
& & $+[$ bodoh sekali $]$ \\
& & $+[$ goblok $]$ \\
& & $+[$ umpatan $]$ \\
\hline
\end{tabular}

Cyberbullying Use on Teenage Artists and Its Implications on Increasing Awareness of ... 
Tabel 4: Contoh Komponen Makna Asusila

\begin{tabular}{|c|c|c|}
\hline Inisial & Komentar & Komponen Makna \\
\hline \multirow[t]{3}{*}{ AT } & Halo imajinasi mesumku & $+[$ kotor $]$ \\
\hline & & $+[$ tidak senonoh $]$ \\
\hline & & $+[$ cabul $]$ \\
\hline \multirow[t]{2}{*}{$\mathrm{AH}$} & Pantat gede & +[bagian tubuh] \\
\hline & & $\begin{array}{l}+[\text { bagian pangkal paha disebelah belakang }] \\
+ \text { anggota badan }]\end{array}$ \\
\hline \multirow[t]{8}{*}{ CK } & Sok korea lu jijik. Lu kira lu cakep? Muka & Jijik \\
\hline & kek memek kebo juga & $+[$ kotor $]$ \\
\hline & & $+[$ sampah $]$ \\
\hline & & + [umpatan] \\
\hline & & Memek \\
\hline & & $+[$ merepek $]$ \\
\hline & & + [vagina] \\
\hline & & + [alat kelamin] \\
\hline \multirow[t]{3}{*}{ BS } & Muka macam peler & + [umpatan] \\
\hline & & $+[$ bola biji $]$ \\
\hline & & +[kelamin pria $]$ \\
\hline \multirow[t]{3}{*}{ KR } & Pingin dong dijilat $\underline{\mathrm{kntlku}}$ & + [alat kelamin laki-laki] \\
\hline & & $+[$ kontol $]$ \\
\hline & & $+[$ zakar $]$ \\
\hline
\end{tabular}

Tabel 5: Contoh Komponen Makna Umpatan

\begin{tabular}{|c|c|c|}
\hline Inisial & Komentar & Komponen Makna \\
\hline AT & Aaaaa keliatan gembrot badanmu wkakaka & $\begin{array}{l}+[\text { gemuk }] \\
+[\text { tidak sintal }] \\
+[\text { umpatan }]\end{array}$ \\
\hline $\mathrm{AH}$ & $\begin{array}{l}\text { Duhh aii soknya pamer betul } \mathrm{cmn} \text { baru } \\
\text { pertama kali masuk } \\
\text { Dsr pelakor }\end{array}$ & $\begin{array}{l}\text { Pamer } \\
+[\text { menyombongkan diri }] \\
+[\text { memperlihatkan kelebihan }] \\
+[\text { tsebuah tindakan }]\end{array}$ \\
\hline & & $\begin{array}{l}\frac{\text { Pelakor }}{+[\text { perebut lelaki orang }]} \\
+ \text { [umpatan }] \\
+ \text { [asusila }]\end{array}$ \\
\hline CK & $\begin{array}{l}\text { Bangsat lo pantas dibully karna muka lo kay- } \\
\text { ak babi tau gk lo }\end{array}$ & $\begin{array}{l}+[\text { tabiat buruk }] \\
+[\text { kutu busuk }] \\
+[\text { umpatan }]\end{array}$ \\
\hline BS & [tahi][tahi] & $\begin{array}{l}+[\text { ampas makanan }] \\
+[\text { tinja }] \\
+[\text { kotoran }]\end{array}$ \\
\hline KR & Alay kelen ah & $\begin{array}{l}+[\text { norak }] \\
+[\text { kampungan }] \\
+[\text { berlebihan }]\end{array}$ \\
\hline
\end{tabular}

280 | LITERA, Volume 18, Nomor 2, Juli 2019 
Tabel 6: Contoh Komponen Makna Tindakan

\begin{tabular}{lll}
\hline Inisial & Komentar & Komponen Makna \\
\hline AT & Pengen banget nidurin @at & $+[$ berbaring] \\
& & $+[$ bersetubuh dengan $]$ \\
& & $+[$ tidur] \\
AH & Njiirrr...Cipokkkjuga ni cwe & $+[$ ciuman yang berbunyi] \\
& & $+[$ aktivitas seksual] \\
& & $+[$ tidak baik $]$ \\
CK & - & - \\
BS & - & - \\
KR & Gila mulus banget tuh paha..Pasti pada pen- - & $+[$ bercinta $]$ \\
& gen wik wik wik sama yg ginian. & $+[$ gairah $]$ \\
& & $+[$ bunyi $]$ \\
\hline
\end{tabular}

Tabel 7: Contoh Komponen Makna Tidak Baik

\begin{tabular}{|c|c|c|}
\hline Inisial & Komentar & Komponen Makna \\
\hline AT & Masih muda tapi kek emak2 anak lima & $\begin{array}{l}\frac{\text { Muda }}{+[\text { belum sampai setengah umur }]} \\
+[\text { belum cukup umur }] \\
+ \text { belum lama ada }] \\
\text { Emak } \\
+[\text { ibu }] \\
+[\text { orang tua perempuan }] \\
+[\text { sebutan untuk yang patut dipanggil ibu }]\end{array}$ \\
\hline $\mathrm{AH}$ & Pentil & $\begin{array}{l}+[\text { puting susu }] \\
+[\text { cembu kecil }] \\
+[\text { organ tubuh }]\end{array}$ \\
\hline CK & Culun & $\begin{array}{l}+[\text { naif }] \\
+[\text { tidak berpengalaman }] \\
+[\text { tidak menyenangkan }]\end{array}$ \\
\hline BS & 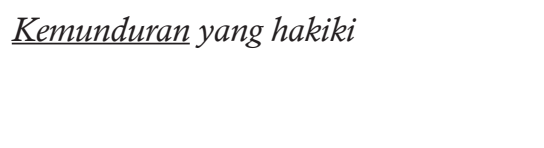 & $\begin{array}{l}+[\text { mundur }] \\
+[\text { bergerak ke belakang }] \\
+[\text { menjadi buruk }]\end{array}$ \\
\hline KR & Gatel & $\begin{array}{l}+ \text { [gatal }] \\
+[\text { geli }] \\
+[\text { suka atau ingin bersetubuh }]\end{array}$ \\
\hline
\end{tabular}

Tabel 2 hingga Tabel 7 menunjukkan contoh-contoh komentar berdasarkan keenam kategori komponen makna (fisik, kasar, asusila, umpatan, tindakan, dan tidak baik). Secara terperinci, masingmasing komentar terpilih memiliki satu hingga tiga buah kata bermakna negatif. Kata-kata tersebut dimaknai melalui komponen makna leksikalnya dengan tujuan untuk mempermudah pendeskripsian makna. Berdasarkan penggambaran temuan komponen makna pada Tabel 1, 
komponen kata yang paling banyak ditemukan pada data komentar di penelitian ini adalah [asusila] [tidak baik] [umpa$\tan ]$.

\section{Pengelompokan Jenis Cyberbullying}

Setelah menganalisis komponen maknanya, komentar-komentar tersebut dikelompokkan ke dalam jenis cyberbullying menurut Willard (2007). Pengelompokkan yang dimaksud Tabel 8 .

Tabel pengelompokan frekuensi jenis cyberbullying menunjukkan ada dua jenis cyberbullying yang paling banyak muncul pada komentar-komentar yang dianalisis. Kedua jenis tersebut adalah harassment dan flaming.

\section{Pembahasan \\ Komponen Makna}

Hasil penelitian ini memberikan gambaran bahwa komponen makna leksikal pada komentar-komentar terpilih yang dijadikan sampel memiliki makna negatif (asusila, tidak baik, dan umpatan). Terlebih terdapat kata-kata yang mengalami pergeseran makna dari makna leksikalnya ketika digunakan pada komentar (Tabel 9-14). Jadi, berdasarkan hasil penelitian komponen makna dan kategori Willard (2007), dapat disimpulkan bahwa cyberbullying pada kolom komentar kelima artis remaja Indonesia ini memang benar-benar terjadi. Contoh komentar yang dicantumkan pada kolom pembahasan ini ditulis apa adanya berdasarkan komentar-komentar yang tertulis pada kolom komentar di Instagram masing-masing artis.

Tabel 8: Frekuensi Jenis Cyberbullying

\begin{tabular}{|c|c|c|c|c|c|c|c|}
\hline & \multicolumn{7}{|c|}{ Jenis Cyberbullying } \\
\hline & Flaming & Harassment & Denigration & Impersonation & $\begin{array}{l}\text { Outing } \\
\text { and } \\
\text { trickery }\end{array}$ & Exclusion & Cyberstalking \\
\hline$\sum$ & 6 & 139 & - & - & - & - & 5 \\
\hline
\end{tabular}

Tabel 9: Pembahasan Makna Leksikal Komentar Berkomponen Makna Fisik

\begin{tabular}{|c|c|c|}
\hline Inisial & Komentar & Analisis Makna Leksikal \\
\hline \multirow[t]{2}{*}{ AT } & Gendut oh gendut.... & [besar] [perut seakan-akan menggantung] [bunting] \\
\hline & & $\begin{array}{l}\text { Kata gendut dalam komentar ini bermakna menilai fisik ses- } \\
\text { eorang. Bentuk komentar seperti ini cenderung menyudutkan } \\
\text { dan dapat menimbulkan ketidaknyamanan terhadap si artis, ter- } \\
\text { lebih penilaian dapat terbaca oleh siapa saja. }\end{array}$ \\
\hline \multirow[t]{2}{*}{$\mathrm{AH}$} & Pepeqnya juga cantik & [pepek] [kemaluan perempuan] [organ tubuh] \\
\hline & & $\begin{array}{l}\text { Komentar ini menggunakan organ intim wanita yang menunjuk- } \\
\text { kan bahwa pemberi komentar memiliki fantasi liar terhadap si } \\
\text { artis. Komentar ini mengarah kepada bentuk seksual verbal yang } \\
\text { ditujukkan kepada artis tersebut saat postingan foto yang diung- } \\
\text { gah membuat gairah seksual mereka meningkat. }\end{array}$ \\
\hline
\end{tabular}




\begin{tabular}{|c|c|c|}
\hline \multirow{2}{*}{$\begin{array}{l}\text { Inisial } \\
C K\end{array}$} & Komentar & Analisis Makna Leksikal \\
\hline & Ga sipit. Sekarang sipit & [tentang mata] [tidak lebar atau bulat] [kecil] \\
\hline BS & Kerempeng badannya & $\begin{array}{l}\text { Komentar ini mengarah kepada bentuk mata si artis namun kon- } \\
\text { teksnya menyudutkan. Penyebabnya adalah karena bentuk mata } \\
\text { si artis yang dianggap mengalami perubahan yang tidak sesuai. } \\
\text { [sangat kurus] [tulang tampak menonjol] [tentang bentuk badan] }\end{array}$ \\
\hline KR & susu udah turun & $\begin{array}{l}\text { Kata kerempeng berdasarkan KBBI mengarah kepada bentuk } \\
\text { badan yang sangat kurus. Komentar ini menunjukkan makna } \\
\text { bahwa si artis mengalami pelecehan bentuk fisik, karena fisik ses- } \\
\text { eorang tidak pantas dilabeli sesuka hati terlebih komentar ini ter- } \\
\text { jadi di media sosial yang dapat bebas terbaca. } \\
\text { [pavudara] [dada] [organ tubuh] }\end{array}$ \\
\hline & & $\begin{array}{l}\text { Penggunaan kata susu pada komentar 'susunya udah turun' meru- } \\
\text { juk pada payudara perempuan. Berdasarkan ketiga komponen } \\
\text { maknanya, tuturan komentar ini merujuk kepada penghinaan } \\
\text { terhadap bagian tubuh yang dianggap tidak menarik. Hal ini } \\
\text { mengarah kepada komentar penghinaan bentuk tubuh yang ter- } \\
\text { masuk ke dalam kategori harassment. }\end{array}$ \\
\hline
\end{tabular}

Tabel 10: Pembahasan Makna Leksikal Komentar Berkomponen Makna Kasar

\begin{tabular}{lll}
\hline Inisial & Komentar & Komponen Makna \\
\hline AT Bacot & [mulut] [banyak omong] [berisik] \\
& Ketiga komponen makna tersebut berasal dari makna leksikal ba- \\
& cot pada KBBI dan kitabgaul.com. Berdasarkan penemuan tersebut, \\
& kata bacot biasanya ditujukan untuk mengungkapkan kekesalan \\
& kepada seseorang yang berisik atau banyak omong. Menariknya, \\
& kata bacot sebenarnya berhubungan dengan komunikasi lisan kare- \\
& na terdapat komponen [mulut] pada pemaknaannya. Namun, jus- \\
& tru kata ini digunakan pada komunikasi tulis. Jadi, berdasarkan \\
& komponen makna kata bacot dapat disimpulkan bahwa komentar \\
& berunsur cyberbullying pada instagram cenderung menggunakan \\
& pola bahasa lisan yang dituliskan. \\
& [perempuan jalang] [wanita] [tunasusila] \\
& \\
& Berasal dari maknal leksikal pada KBBI, kata lonte ditujukan untuk \\
& menjuluki orang-orang yang bekerja sebagai pemuas nafsu. Kata ini \\
& biasanya merupakan sebuah umpatan sehingga ia memiliki konotasi \\
& negatif di mata masyarakat. Komponen makna kata lonte memperli- \\
& hatkan bahwa komentar yang ditujukan kepada AH ini merupakan \\
& sebuah bentuk penghinaan dan dapat digolongkan sebagai bentuk cy- \\
& berbullying karena komentar tersebut bersifat merendahkan. \\
\hline
\end{tabular}

Cyberbullying Use on Teenage Artists and Its Implications on Increasing Awareness of ... 


\begin{tabular}{|c|c|c|}
\hline Inisial & Komentar & Komponen Makna \\
\hline \multirow[t]{9}{*}{$\mathrm{CK}$} & Idung nya itu loh & $\underline{B a b i}=$ [binatang] [umpatan] [kasar] \\
\hline & kayak hidung babi & $\underline{\text { Haram }}=[$ terlarang] [tidak sah] [tidak boleh] \\
\hline & wkwk dah tu sok can- & \\
\hline & $\begin{array}{l}\text { tik pulak lo babi lo } \\
\text { sama kakak mama lo }\end{array}$ & $\begin{array}{l}\text { Pada pemaknaan kata babi yang ditemukan dalam KBBI menga- } \\
\text { rah kepada hewan, namun dalam konteks ini penggunaan nama }\end{array}$ \\
\hline & $\begin{array}{l}\text { yang sok cantik anak } \\
\text { haram lo }\end{array}$ & $\begin{array}{l}\text { hewan digunakan sebagai kata hinaan yang mendeskripsikan si } \\
\text { artis sebagai manusia mirip dengan babi sebagai hewan. Selanjut- }\end{array}$ \\
\hline & & nya, penggunaan kata haram yang berkolokasi menjadi anak ha- \\
\hline & & $\begin{array}{l}\text { ram adalah sebuah pelabelan negatif yang dilakukan oleh si pem- } \\
\text { beri komentar. Hal ini bersifat hinaan karena berkonotasi pada }\end{array}$ \\
\hline & & $\begin{array}{l}\text { anak yang lahir dari hubungan yang tidak resmi. Terlebih, penghi- } \\
\text { naan vang dialami CK ini turut dikaitkan dengan keluarganya se- }\end{array}$ \\
\hline & & $\begin{array}{l}\text { hingga hal ini dirasa membuat sekeluarga kembali turut terhina } \\
\text { dalam kolom komentar. }\end{array}$ \\
\hline \multirow[t]{2}{*}{ BS } & Mau mati ga? & [sudah hilang nyawa] [tidak hidup lagi] [tidak pernah hidup] \\
\hline & & $\begin{array}{l}\text { Pemaknaan kata mati pada kalimat tanya ini adalah bahwa si } \\
\text { pemberi komentar cenderung mengancam dan mengintimidasi si } \\
\text { artis. Penggunaan kata "mati" di sini dapat juga dimaknai sebagai } \\
\text { menantang si artis untuk lebih baik kehilangan nyawanya sehing- } \\
\text { ga komentar ini dapat dikategorikan ke dalam cyberstalking ter- } \\
\text { lebih jika terjadi sebuah tindakan pasca ancaman ini. }\end{array}$ \\
\hline \multirow[t]{2}{*}{$\mathrm{KR}$} & $\begin{array}{l}\text { Lubang idung kegedean } \\
\text { woy kontrol gblk }\end{array}$ & [bodoh sekali] [goblok] [umpatan] \\
\hline & & $\begin{array}{l}\text { Pemakaian singkatan gblk merupakan hal yang biasa terjadi di ka- } \\
\text { langan anak muda zaman sekarang dengan tujuan memperhalus, } \\
\text { meskipun makna tetap sama. Gblk berarti goblok bertujuan untuk } \\
\text { menghina si artis atas gaya swafoto yang dibagikannya di laman } \\
\text { Intagram pribadinya. Komentar ini menunjukkan bagaimana ba- } \\
\text { hasa digunakan dengan kasar untuk mengomentari seseorang. }\end{array}$ \\
\hline
\end{tabular}

Tabel 11: Pembahasan Makna Leksikal Komentar Berkomponen Makna Asusila

\begin{tabular}{lll}
\hline Inisial & Komentar & Komponen Makna \\
\hline AT & Halo imajinasi mesumku & [kotor] [tidak senonoh] [cabul]
\end{tabular}

Kata mesum di dalam penggunaannya pada komentar ini bermakna bahwa si pemberi komentar menjadikan si artis sebagai objek fantasinya untuk memuaskan nafsu birahinya. Komentar seperti ini sudah termasuk ke dalam sexual harassment yang menjadikan lawan jenis sebagai objek pemenuhan kepuasan khayalan seksnya. 


\begin{tabular}{|c|c|c|}
\hline Inisial & Komentar & Komponen Makna \\
\hline \multirow[t]{2}{*}{$\mathrm{AH}$} & Pantat gede & $\begin{array}{l}\text { [bagian tubuh] [bagian pangkal paha disebelah belakang] } \\
\text { [anggota badan] }\end{array}$ \\
\hline & & $\begin{array}{l}\text { Komentar ini mengomentari ukuran salah satu bagian tubuh } \\
\text { artis tersebut. Bentuk komentar seperti ini mengarah kepada } \\
\text { pelecehan seksual secara tidak langsung dapat menimbulkan } \\
\text { ketidaknyamanan dan merugikan si artis karena komentar } \\
\text { ini bisa mengarahkan pembaca lainnya berpikiran yang sa- } \\
\text { ma dan berfantasi. }\end{array}$ \\
\hline \multirow[t]{3}{*}{ CK } & Sok korea lu jijik. Lu kira lu & $\underline{\text { Jijik }}=[$ kotor $][\mathrm{sampah}][$ umpatan $]$ \\
\hline & $\begin{array}{l}\text { cakep? Muka kek memek kebo } \\
\text { juga }\end{array}$ & $\underline{\text { Memek }}=[$ merepek] [vagina] [alat kelamin] \\
\hline & & $\begin{array}{l}\text { Kata pertama yaitu jijik memiliki makna yang mengarah ke- } \\
\text { pada suatu hinaan yang diberikan kepada artis yang dituju } \\
\text { dikarenakan penampilannya yang tidak disukai oleh si pem- } \\
\text { beri komentar. Lalu, penggunaan kata memek, berdasarkan } \\
\text { pemaknaan pada fungsinya di kalimat ini, mengarah kepada } \\
\text { hinaan yang merendahkan artis tersebut, terlebih kata memek } \\
\text { disandingkan dengan hewan kerbau (kebo). Bentuk komentar } \\
\text { ini merupakan cyberbullying terhadap artis CK karena meng- } \\
\text { arah kepada penghinaan yang membuat ketidaknyamanan } \\
\text { dan melanggar norma kesopanan. }\end{array}$ \\
\hline \multirow[t]{2}{*}{ BS } & Muka macam peler & [umpatan] [bola biji] [kelamin pria] \\
\hline & & $\begin{array}{l}\text { Kata peler yang berarti alat kelamin pria disandingkan de- } \\
\text { ngan muka dari si artis sungguh bukan padu padan yang } \\
\text { pantas dan mengarah ke asusila. Tidak hanya ketidakpan- } \\
\text { tasan bahasa yang digunakan, penggunaan kata peler di } \\
\text { dalam kolom komentar menunjukkan ketidaksopanan dari } \\
\text { pemberi komentar. Komentar seperti ini sudah dapat dikate- } \\
\text { gorikan ke dalam sexual harassment. }\end{array}$ \\
\hline \multirow[t]{2}{*}{$\mathrm{KR}$} & Pingin dong dijilat $\underline{\mathrm{kntl} k u}$ & [alat kelamin laki-laki] [kontol] [zakar] \\
\hline & & $\begin{array}{l}\text { Kata kntl merupakan singkatan dari kontol yang bermakna } \\
\text { asusila di dalam komentar ini. Penilaian asusila disebabkan } \\
\text { oleh harapan si pemberi komentar yang berkeinginan untuk } \\
\text { melakukan tidak sesuai norma dengan si artis. Komentar ini } \\
\text { kembali membuktikan sexual harassment terjadi di media so- } \\
\text { sial. }\end{array}$ \\
\hline
\end{tabular}

Cyberbullying Use on Teenage Artists and Its Implications on Increasing Awareness of ... 
Tabel 12: Pembahasan Makna Leksikal Komentar Berkomponen Makna Umpatan

\begin{tabular}{|c|c|c|}
\hline Inisial & Komentar & Komponen Makna \\
\hline AT & $\begin{array}{l}\text { Aaaaa keliatan gembrot badan- } \\
\text { mu wkakaka }\end{array}$ & [gemuk] [tidak sintal] [umpatan] \\
\hline \multirow[t]{2}{*}{$\mathrm{AH}$} & $\begin{array}{l}\text { Duhh aii soknya pamer betul } \\
\text { cmn baru pertama kali masuk } \\
\text { Dsr pelakor }\end{array}$ & $\begin{array}{l}\text { Pamer }=\text { [menyombongkan diri }] \text { [memperlihatkan kelebi- } \\
\text { han] [tsebuah tindakan] } \\
\text { Pelakor }=\text { [perebut lelaki orang] [umpatan] [asusila }]\end{array}$ \\
\hline & & $\begin{array}{l}\text { Berdasarkan komponen dari dua kata yang merujuk pada } \\
\text { perundungan diatas, komentar tersebut menyudutkan artis } \\
\text { dan menuliskan bentuk hinaan yang dapat merugikan artis. } \\
\text { Sementara pada komentar 'pelakor' dimana tidak terdapat } \\
\text { pada KBBI, namun istilah ini umum digunakan pada saat } \\
\text { ini yang bermakna dimana seorang perempuan melakukan } \\
\text { perbuatan tercela dengan merebut atau menggoda suami se- } \\
\text { seorang yang sah dan telah memiliki ikatan pernikahan se- } \\
\text { cara hukum, sehingga dapat menimbulkan kerugian pada } \\
\text { rumah tangga yang menjadi korban. }\end{array}$ \\
\hline \multirow[t]{2}{*}{ CK } & $\begin{array}{l}\text { Bangsat lo pantas dibully karna } \\
\text { muka lo kayak babi tau gk lo }\end{array}$ & [tabiat buruk] [kutu busuk] [umpatan] \\
\hline & & $\begin{array}{l}\text { Komponen makna kata bangsat yang diambil dari KBBI } \\
\text { menunjukkan sebuah ungkapan kekesalan yang ditujukan } \\
\text { untuk menghina, dalam kasus ini kepada artis CK. Kata } \\
\text { bangsat merupakan kata yang biasanya digunakan sebagai } \\
\text { bahasa lisan untuk mengumpat. Pada kalimat tersebut, pem- } \\
\text { beri komentar dengan sadar mengetahui bahwa apa yang ia } \\
\text { lakukan merupakan bentuk perundungan. Fakta lainnya, } \\
\text { komentar ini menunjukkan penghinaan dengan menggunak- } \\
\text { an kata babi yang digunakan untuk menyamakan artis seb- } \\
\text { agai manusia dengan hewan. Di sini, cyberbullying dan } \\
\text { bodyshaming lagi-lagi terjadi. }\end{array}$ \\
\hline \multirow[t]{2}{*}{ BS } & [tahi][tahi] & [ampas makanan] [tinja] [kotoran] \\
\hline & & $\begin{array}{l}\text { Komentar tahi ini sebenarnya berupa emotikon berbentuk } \\
\text { tahi, sehingga akhirnya diverbalkan untuk kepentingan anal- } \\
\text { isis pada penelitian ini. Tahi menurut KBBI adalah kotoran. } \\
\text { Jika dikaitkan dengan komentar yang dikirimkan maka me- } \\
\text { nyatakan umpatan atau ketidaksukaan kepada si artis atas } \\
\text { foto yang diunggahnya. }\end{array}$ \\
\hline \multirow[t]{2}{*}{ KR } & Alay kelen ah & [norak] [kampungan] [berlebihan] \\
\hline & & $\begin{array}{l}\text { Penggunaan kata alay pada komentar ini menunjukkan keti- } \\
\text { daksukaan si pemberi komentar terhadap foto unggahan si } \\
\text { artis. Istilah alay merupakan istilah kekinian yang biasanya } \\
\text { ditujukan untuk menyatakan segala sesuatu yang dianggap } \\
\text { berlebihan oleh si penilai. }\end{array}$ \\
\hline
\end{tabular}

286 | LITERA, Volume 18, Nomor 2, Juli 2019 
Tabel 13: Pembahasan Makna Leksikal Komentar Berkomponen Makna Tindakan

\begin{tabular}{|c|c|c|}
\hline Inisial & Komentar & Komponen Makna \\
\hline \multirow[t]{2}{*}{ AT } & Pengen bangetnidurin@at & [berbaring] [bersetubuh dengan] [tidur] \\
\hline & & $\begin{array}{l}\text { Ketiga komponen makna itu mengarahkan kepada anggapan } \\
\text { bahwa si pemberi komentar memiliki fantasi seksual untuk bisa } \\
\text { bersetubuh dengan si artis. Pengategorian tindakan pada kom- } \\
\text { ponen makna ini didasari atas kata yang digunakannya di } \\
\text { dalam berkomentar yang menyatakan ingin melakukan aktivi- } \\
\text { tas. Komentar seperti ini dapat dikategorikan ke dalam sexual } \\
\text { harassment. }\end{array}$ \\
\hline \multirow[t]{2}{*}{$\mathrm{AH}$} & $\begin{array}{l}\text { Njiirrr...Cipokkkjuga ni } \\
\text { cwe }\end{array}$ & [ciuman yang berbunyi] [aktivitas seksual] [tidak baik] \\
\hline & & $\begin{array}{l}\text { Pada ketiga komponen pemaknaan yang disebut berdasarkan } \\
\text { unggahan artis, pembaca unggahan tersebut melihat foto terse- } \\
\text { but dan menyerukan untuk melakukan aktivitas seksual yang } \\
\text { disebutkan pada artis tersebut. Bentuk ungkapan yang mereka } \\
\text { unggah pada kolom komentar dalam unggahan artis tersebut } \\
\text { mengarah kepada sexual harassment. }\end{array}$ \\
\hline $\mathrm{CK}$ & - & - \\
\hline BS & - & - \\
\hline \multirow[t]{2}{*}{$\mathrm{KR}$} & $\begin{array}{l}\text { Gila mulus banget tuh pa- } \\
\text { ha..Pasti pada pengen wik }\end{array}$ & [bercinta] [gairah] [bunyi] \\
\hline & wik wik sama yg ginian. & $\begin{array}{l}\text { Wik wik wik merupakan tuturan bunyi yang berasal dari sebuah } \\
\text { lagu berbahasa Thailand yang berarti aku mencintaimu. Pada } \\
\text { konteks video lagunya, bunyi wik wik wik disuarakan ketika } \\
\text { adegan mengarah kepada hubungan seksual. Kaitannya de- } \\
\text { ngan tuturan komentar untuk artis KR adalah adanya pemak- } \\
\text { naan mengajak untuk bercinta atau melakukan hubungan sek- } \\
\text { sual. Wik wik wik sendiri belum terdaftar makna leksikalnya di } \\
\text { KBBI. Kemungkinan penggunaan wik wik wik dipengaruhi pa- } \\
\text { da fenomena daring yang populer di tengah masyrakat terkait } \\
\text { judul lagu yang sama dengan wik wik wik tersebut. }\end{array}$ \\
\hline
\end{tabular}

Tabel 14: Pembahasan Makna Leksikal Komentar Berkomponen Makna Tidak Baik

\begin{tabular}{|c|c|c|}
\hline Inisial & Komentar & Komponen Makna \\
\hline \multirow[t]{2}{*}{ AT } & $\begin{array}{l}\text { Masih muda tapi kek } \\
\text { emak2 anak lima }\end{array}$ & $\begin{array}{l}\underline{M u d a}=\text { [belum sampai setengah umur] [belum cukup umur] } \\
\text { belum lama ada] } \\
\text { Emak }=[\text { ibu] [orang tua perempuan] [sebutan untuk yang patut } \\
\text { dipanggil ibu] }\end{array}$ \\
\hline & & $\begin{array}{l}\text { Berdasarkan makna leksikal yang diperoleh dari KBBI, pemak- } \\
\text { naan komentar ini adalah bahwa si artis memperoleh hinaan } \\
\text { pada penampilannya dengan cara membandingkan umurnya } \\
\text { dengan gaya ibu-ibu di atas umurnya. Komentar ini dikategori- } \\
\text { kan ke dalam komponen makna tidak baik karena adanya ke- } \\
\text { cenderungan menghina. }\end{array}$ \\
\hline
\end{tabular}

Cyberbullying Use on Teenage Artists and Its Implications on Increasing Awareness of ... 


\begin{tabular}{|c|c|c|}
\hline Inisial & Komentar & Komponen Makna \\
\hline \multirow[t]{2}{*}{$\mathrm{AH}$} & Pentil & [puting susu] [cembu kecil] [organ tubuh] \\
\hline & & $\begin{array}{l}\text { Komponen makna pada kata pentil berdasarkan KBBI menga- } \\
\text { rah kepada bagian tubuh pada manusia. Komentar ini dikate- } \\
\text { gorikan ke dalam komponen makna tidak baik karena kontek- } \\
\text { snya menghina si artis dengan mengarahkan komentar ke pada } \\
\text { salah satu bagian tubuh privatnya. }\end{array}$ \\
\hline \multirow[t]{2}{*}{ CK } & Culun & [naif] [tidak berpengalaman] [tidak menyenangkan] \\
\hline & & $\begin{array}{l}\text { Berdasarkan pemaknaan leksikal yang ditemukan di KBBI kata } \\
\text { culun mengarah pada perilaku atau penampilan yang naif. Pada } \\
\text { komentar yang diunggah pun merujuk pada penampilan artis } \\
\text { CK yang dianggap pengunggah komentar tidak modis dan ti- } \\
\text { dak menarik sehingga akhirnya komentar ini pun turut dikate- } \\
\text { gorikan ke dalam komponen makna tidak baik. }\end{array}$ \\
\hline \multirow[t]{2}{*}{ BS } & Kemunduran yang hakiki & [mundur] [bergerak ke belakang] [menjadi buruk] \\
\hline & & $\begin{array}{l}\text { Ketiga komponen makna tersebut berasal dari makna leksikal } \\
\text { kemunduran pada KBBI. Penggunaan kata kemunduran pada ko- } \\
\text { mentar tersebut cenderung mengarah kepada makna negatif } \\
\text { karena merujuk pada pergerakan menjadi mundur ke belakang. } \\
\text { Hal ini dapat dikategorikan ke dalam harassment karena adanya } \\
\text { indikasi menghina si artis BS atas keputusannya mengunggah } \\
\text { foto tertentu. }\end{array}$ \\
\hline \multirow[t]{2}{*}{ KR } & Gatel & [gatal] [geli] [suka atau ingin bersetubuh] \\
\hline & & $\begin{array}{l}\text { Kata gatel pada komentar ini berdasarkan komponen maknanya } \\
\text { dapat dimaknai sebagai bentuk ketidaksukaan si pemberi ko- } \\
\text { mentar terhadap si artis. Komentar ini cenderung menimbulkan } \\
\text { dua buah perspektif, ketidaksukaan terhadap pribadi si artis } \\
\text { atau pada foto unggahannya. Ketiga komponen makna tersebut } \\
\text { pada akhirnya dikategorikan ke dalam komponen makna tidak } \\
\text { baik karena menghina si artis. }\end{array}$ \\
\hline
\end{tabular}

Pembahasan pada Tabel 9-14 mengarahkan kepada sebuah kenyataan bahwa bentuk perundungan yang paling banyak terjadi pada kolom komentar kelima artis remaja Indonesia (AT, AH, CK, BS, dan KR) berupa penghinaan dan pelecehan bentuk tubuh. Pada kolom komentar AT, $\mathrm{CK}$, dan $\mathrm{KR}$, tanggapan terbanyak ditemukan tentang bentuk bagian tubuh mereka, terutama payudara. Sementara
$\mathrm{AH}$ memperoleh komentar yang kebanyakan berisi pendapat terkait penampilan wajah artis tersebut yang dianggap tidak sesuai dengan usianya. Terlebih isu operasi plastik yang mengiringi beberapa artis dalam penelitian ini pun turut diduga menjadi alasan cyberbullying terjadi. Armalita \& Helmi (2018) menemukan adanya kaitan antara penilaian deservingness dan iri yang muncul saat melihat ke- 
suksesan orang lain. Penelitiannya mendapati bahwa iri semakin meningkat ketika seseorang melihat postingan KUR (Kesuksesan Usaha Rendah).

Sementara itu, terdapat tindakan $c y$ berbullying yang sama bagi keempat artis remaja perempuan ini yaitu sama-sama memperoleh pelecehan seksual secara verbal oleh komentator laki-laki yang merasa terangsang saat melihat unggahan foto artis tersebut. Dwiyanti (2014) mengungkapkan bahwa pelecehan seksual adalah penyalahgunaan kekuasaan serta ekspresi dari seksualitas laki-laki. Menariknya, di sisi lain, BS sebagai satusatunya artis remaja laki-laki di dalam penelitian ini pun mengalami kemiripan kasus dimana komentator perempuan jusru memuji fisik si artis ketimbang komentator laki-laki yang cenderung menyudutkan si artis.

Pada akhirnya, analisis dalam penelitian ini menyimpulkan dua hal terkait fenomena cyberbullying yang ditemukan. Pertama, perundungan dapat berasal dari relasi posisi yang menyatakan siapa yang memegang kendali atas posisi superiornya. Kedua, baik laki-laki dan perempuan pelaku cyberbullying yang ditemukan pada penelitian ini umumnya memiliki sasaran merundung yang sama, yaitu tubuh kelima artis remaja yang terbingkai dalam foto yang mereka unggah di akun Instagram masing-masing.

\section{Pengelompokan Jenis Cyberbullying}

Berdasarkan hasil analisis pengelompokan jenis cyberbullying (Willard, 2007), terdapat tiga jenis yang ditemukan di dalam penelitian ini (Gambar 2). Dengan total data komentar pada penelitian ini sebanyak 150 tuturan, harassment menem- pati urutan pertama dengan frekuensi kemunculan sebanyak 139 tuturan (93\%). Kedua adalah flaming sebanyak 6 tuturan (4\%). Ketiga adalah cyberstalking sebanyak 5 tuturan (3\%). Hal ini sejalan dengan penelitian Utami \& Baiti (2018) yang menemukan harassment sebagai tindakan cyberbullying yang paling banyak ditemukan, yaitu sebesar 18.8\%.

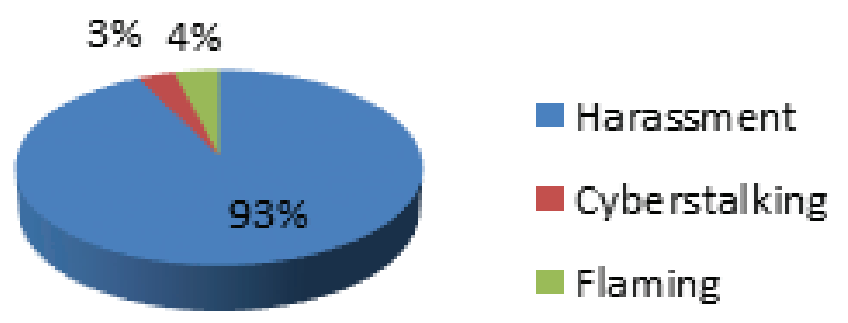

Gambar 2: Persentase Frekuensi Jenis cyberbullying

Perundungan yang terjadi pada komentar-komentar untuk unggahan foto para artis remaja Indonesia di akun Instagram mereka didominasi oleh pengiriman pesan yang bersifat menyerang, kasar, dan berunsur penghinaan (harassment). Pada posisi kedua adalah pesanpesan elektronik bernada penuh kekesalan dengan bahasa yang kasar (flaming). Kemudian, tindakan terakhir yang terjadi adalah pengiriman pesan yang mengandung unsur mengintimidasi sehingga dapat membuat si penerima pesan merasa dalam bahaya dan takut akan keselamatannya (cyberstalking).

Alasan pertama yang paling memungkinkan terjadinya ketiga jenis cyberbullying ini adalah rasa seakan mengetahui keseluruhan hidup si artis padahal bisa jadi tidak sama sekali. Terlebih, kebanyakan akun pelaku cyberbullying yang 
ditemukan dalam penelitian ini adalah akun yang diduga bukan akun utama si pelaku; dengan ciri: tanpa foto profil, tidak ada unggahan foto pada laman pribadinya, atau berupa akun privat dan terkunci. Rasa aman si pelaku karena anonimitas inilah yang semakin memperbesar penghinaan di Instagram para artis dalam penelitian ini. Li (2007) menemukan bahwa hampir setengah dari korban di dunia siber bahkan tidak mengetahui siapa yang merundung mereka karena para pelaku merasa tidak perlu berhadapan langsung dengan korban dan mereka dapat menyembunyikan identitasnya sehingga merasa dapat menghindari konsekuensi atas cyberbullying yang dilakukannya. Sejalan dengan ini, Pratiwi (2011) menyatakan bahwa pelaku cyberbullying menjadi lebih berani mengekspresikan perasaannya di dunia maya karena efek disinhibisi online yang menjadikan pelaku tidak terjangkau oleh korban.

Alasan kedua yang dirasa dapat menjadi penyebab terjadinya cyberbullying pada kelima artis tersebut adalah standar bercanda setiap individu. Rachmatan (2017) dalam penelitiannya menemukan bahwa banyak remaja yang menjadi pelaku perundungan siber menganggap tindakan perundungannya adalah sebagai bentuk "bercandaan". Hal ini sejalan dengan penelitian Sartana dan Afriyeni (2017) yang mendapatkan bahwa alasan utama remaja melakukan perundungan maya adalah untuk bercanda, ingin balas dendam, atau karena mereka marah atau membenci korban. Hal ini sejalan dengan temuan pada penelitian ini yang turut mendapati banyak kata celaan namun terkesan bercanda.
Ada banyak alasan lainnya penyebab terjadinya cyberbullying. Namun, yang terpenting, hasil pengelompokan pada penelitian ini membuktikan bahwa cyberbullying terjadi ketika pesan atau komentar menggunakan kata-kata yang berunsur penghinaan dan mengintimidasi. Pelaporan terhadap tindakan cyberbullying ini tentu bisa dilakukan karena pasal 27 ayat 3 Undang-Undang No. 11 tahun 2008 tentang Informasi dan Transaksi Elektronik dapat digunakan untuk membawa komentar bermuatan penghinaan dan/atau pencemaran nama baik pada dunia siber masuk ke ranah hukum di dunia nyata.

\section{Implikasi}

Notar, Padgett, \& Roden (2013) menegaskan bahwa cyberbullying seringkali terjadi sebagai bentuk lanjutan perundungan yang terjadi di dunia nyata dan belum terselesaikan dengan benar. Modecki dkk (2014) pun turut menemukan bahwa biasanya kaum muda yang terlibat dalam $c y$ ber bullying juga terlibat dalam traditional bullying, khususnya relational bullying. Sejalan dengan kenyataan tersebut, Kraft \& Wang (2009) mengungkapkan fakta bahwa para siswa yang melakukan perundungan memberikan solusi terhadap aksi cyberbullying, yaitu pemberian hukuman yang membatasi mereka dalam penggunaan internet dan teknologinya. Oleh karena itu, sekolah yang bersinergi dengan orang tua dan lingkungan pertemanan anak di sekolah dianggap bisa mengurangi cyberbullying. Berikut adalah implikasi untuk peningkatan kesantunan remaja dalam berbahasa, keterbukaan komunikasi orang tua, kesigapan masyarakat, dan kesadaran terhadap pendidikan seks. 


\section{Peningkatan Kesantunan Remaja dalam Berbahasa}

Peningkatan pengajaran berbahasa yang baik dan benar bagi remaja dirasa perlu guna menyadarkan remaja pentingnya berempati dan bersikap santun di dalam mengolah kata dan menggunakan bahasa. Rahayu (2015) berpendapat bahwa bahasa Indonesia adalah bahasa yang mampu menjembatani jurang komunikasi antar suku yang memiliki bahasa daerah yang berbeda-beda. Memang, bahasa Indonesia sejatinya adalah bahasa persatuan bangsa Indonesia sesuai dengan yang ditetapkan dalam Sumpah Pemuda, namun pergeseran fungsi ini menuju ke arah negatif. Hal ini dapat tergambarkan melalui hasil temuan jenis $c y$ berbullying yang paling sering muncul pada penelitian ini, yaitu harassment dan flaming. Frekuensi kemunculan yang tinggi terhadap dua jenis itu (Gambar 2) membuktikan bahwa cyberbullying terjadi dengan kata-kata bermakna negatif. Terlebih, hasil analisis komponen makna pada penelitian ini pun turut mendukung fungsi bahasa yang disalahgunakan. Hal ini dapat dijadikan contoh peranan bahasa Indonesia tidak lagi sebagai alat pemersatu, tetapi cenderung sebagai alat pemecah belah masyarakat Indonesia.

Adam (2017) mengemukakan bahwa perubahan-perubahan menuju ke arah yang negatif harus segera diantisipasi dengan merevitalisasi kembali pendidikan, terutama yang menyangkut penggunaan bahasa Indonesia yang baik dan benar. Jadi, edukasi terhadap fungsi dan penggunaan bahasa Indonesia yang baik dan benar ada baiknya dilakukan secara berkesinambungan, menyeluruh, dan sedini mungkin terhadap anak-anak dan remaja.

\section{Peningkatan Keterbukaan Komunikasi Orang Tua}

Orang tua sebaiknya membangun komunikasi yang baik dan terbuka dengan anak-anaknya. Satalina (2014) menyatakan faktor-faktor yang dapat mempengaruhi cyberbullying di antaranya adalah bullying tradisional, karakteristik kepribadian, persepsi terhadap korban, strain, serta peran interaksi orang tua dan anak. Sejalan dengan itu, Arofa, Hudainah, dan Zulfiana (2018) mengungkapkan bahwa pola asuh keluarga merupakan hal penting yang berpengaruh dalam timbulnya perilaku bullying. Oleh karena itu, orang tua diharapkan dapat membina komunikasi yang tepat yaitu sesuai usia dan kebutuhan anak. Utami (2013) menemukan bahwa dampak dari cyberbullying mengakibatkan perubahan sikap dan timbulnya pengucilan terhadap korban.

Rifauddin (2016) menyatakan bahwa perilaku cyberbullying dapat memberikan dampak negatif, antara lain korban mengalami depresi, kecemasan, ketidaknyamanan, prestasi di sekolah menurun, tidak mau bergaul dengan teman-teman sebaya, menghindar dari lingkungan sosial, dan adanya upaya bunuh diri. Sejalan dengan pernyataan pada penelitian-penelitian terdahulu tersebut, hasil pada penelitian ini menunjukkan bahwa komentarkomentar yang ditujukan kepada para artis remaja Indonesia ini memiliki komponen makna asusila, tidak baik, dan umpatan. Hal ini tentu akan memberikan efek negatif. Jadi, harapannya, jalinan komunikasi yang baik antara anak dan orang tua dapat menimbulkan rasa nyaman kepada anak untuk bercerita segala kejadian dan perasaan yang dialaminya. 


\section{Peningkatan Kesigapan Masyarakat}

Masyarakat ada baiknya turut serta berperan aktif dalam memerangi cyberbullying. Masyarakat di sini maksudnya seluruh lapisan sosial, baik dimulai dari lingkungan keluarga, pertemanan, sekolah, pemerintah, hingga masyarakat pada umumnya. Memang pasal 29 UU ITE terkait perbuatan mengancam atau menakut-nakuti di dunia siber telah dikeluarkan oleh pemerintah untuk mewadahi fenomena ini, namun sebenarnya peran lingkungan sekitar mengambil porsi lebih banyak. Menyadari bahwa perundungan itu nyata dan mengambil langkah nyata dalam mengatasi perundungan di lingkungan sekitarnya tentu sangat membantu meminimalisir perundungan baik di dunia nyata mapun siber. Rochman (2016) pun turut menyatakan bahwa setiap individu memerlukan pengetahuan dan kebijakan terhadap perilaku bully dan hate speech melalui media sosial untuk menghindari dampaknya. Selain itu, masyarakat pun sudah seharusnya tidak melupakan fungsi media sosial sebagai media komunikasi. Gonzales (2014) mengingatkan bahwa saat pertama membuat akun, pengguna media sosial sebaiknya perlu memahami sisi positif dan negatif, kegunaan, tujuan, kemampuan, dan kemungkinan efek yang akan terjadi melalui media sosialnya. Jadi, edukasi melalui pesan layanan masyarakat, organisasi masyarakat dan pemuda, dan komunitas-komunitas yang berkembang di masyarakat adalah hal yang harus digalakkan.

\section{Kesiapan terhadap Pendidikan Seks}

Pendidikan seks sudah seharusnya diajarkan sejak dini. Pendidikan seks bu- kanlah tentang mendukung anak untuk melakukan hubungan seksual, tapi menjelaskan fungsi alami seks sebagai bagian diri mereka serta konsekuensinya jika disalagunakan (Ratnasari, 2016). Dengan kata lain, tujuannya adalah untuk mempersiapkan anak sedini mungkin terhadap konsep seks dan bentuk pelecehannya yang tidak hanya berupa perbuatan tapi juga perkataan. Keluarga dan sekolah berperan penting dalam hal ini agar tidak ada tindakan pelecehan yang berkembang liar dan keingintahuan terhadap seksualitas lawan jenis yang disikapi dengan salah. Tidak dapat dihindari bahwa informasi terkait seks semakin terbuka seiring kemajuan teknologi, maka lebih baik pendidikan seks diajarkan dengan tepat dan tidak lagi menganggap bahwa pendidikan seks adalah kegiatan pembelajaran yang tabu untuk disampaikan ke anak.

Sudah saatnya orang tua dan sekolah mengambil peran nyata dalam pendidikan seks bagi anak, tentu dengan mempertimbangkan kondisi si anak (umur, kemampuan berbahasa, pola pikir, d1l). Pada dasarnya, perlu disadari oleh orang tua dan sekolah bahwa pendidikan seks dapat diberikan dengan tanpa harus diawali dari sebuah peristiwa dan dapat menyesuaikan dengan kebutuhan anak (Lestari, 2015). Roqib (2008) menyimpulkan bahwa alasan pendidikan seks diberikan lebih awal adalah karena karakter dasar manusia itu dibentuk pada masa kanak-kanak sehingga pendidikan seks pada anak usia dini memiliki kemungkinan untuk dapat meluruskan pemahaman dan perilaku seks anak-anak sehingga bisa lebih positif. Jadi, lagi-lagi edukasi adalah jalan keluarnya. 


\section{SIMPULAN}

Hasil penelitian ini menunjukkan bahwa perkembangan teknologi membawa perilaku komunikasi memiliki sisi negatif yaitu cyberbullying di Instagram. Remaja adalah pelaku sekaligus korban yang dekat dengan hal tersebut. Cyberbullying yang ditemukan pada penelitian ini adalah komentar-komentar penghinaan dan pelecehan bentuk fisik dengan komponen maknanya adalah negatif, kasar, dan tidak baik. Pada penelitian ini, cyberbullying terjadi dalam tiga kategori yaitu harassment, flaming, dan cyberstalking. Hasil ini memberikan empat implikasi terhadap peningkatan kesadaran akan perudungan pada remaja. Pertama, edukasi terhadap kesadaran akan penggunaan bahasa Indonesia yang baik dan benar harus ditingkatkan karena nyatanya fungsi bahasa yang disalahgunakan dapat menyakiti dan berdampak negatif.

Kedua, komunikasi antara orang tua dan anak-anak mereka sebaiknya dijalin dengan baik dan terbuka. Ketiga, mengedukasi masyarakat untuk sadar dan berperan aktif dalam meminimalisir cyberbullying. Langkah ini sebaiknya dilakukan lebih masif karena seringkali para korban perundungan merasa malu untuk sekadar bercerita tentang apa yang dialami. Perbedaan nilai yang berkembang di masyarakat biasanya cenderung menyudutkan korban karena adanya anggapan perundungan dan pelecehan bukan sebuah tindak kejahatan. Keempat, pendidikan seks perlu diajarkan sejak dini baik oleh keluarga maupun sekolah untuk mengurangi pelecehan verbal dan non-verbal terhadap lawan jenis.

Bila sedang dalam posisi sebagai korban cyberbullying disarankan untuk beru- saha mengontrol emosi ketika membaca kalimat jahat dari pelaku, kemudian cobalah istirahat dan menjauhi komputer ataupun gawai untuk sesaat. Ada baiknya membangun komunikasi di dunia nyata dengan berani bercerita kepada orang yang dipercaya bahwa kita mengalami cyberbullying karena bercerita dapat mengurangi tekanan. Usahakan untuk tidak membalas komentar, cukup simpan bukti komentar berunsur cyberbullying tersebut guna melapor kepada pihak yang berwajib. Sudah seharusnya, penyalahgunaan bahasa disikapi tegas. Tentunya semua dampak serta saran yang telah disampaikan akan terlaksana dengan baik bila seluruh masyarakat dapat menyadari apa cyberbullying itu dan mau bergerak melawannya. Pada akhirnya, edukasi yang tepat sasaran di setiap lapisan masyarakat dan komunikasi yang efektif diharapkan dapat mengurangi fenomena cyberbullying di kalangan remaja.

\section{UCAPAN TERIMA KASIH}

Ucapan terima kasih disampaikan kepada semua pihak yang telah membantu dalam penyusunan artikel ini. Kami juga menghaturkan terima kasih kepada program studi Linguistik Universitas Pendidikan Indonesia untuk pembelajarannya. Turut pula ucapan terima kasih kami sampaikan kepada pengelola jurnal Litera atas kesediaannya membaca, memberikan masukan, dan memublikasikan artikel ini.

\section{DAFTAR PUSTAKA}

Adam, S. (2017). Perkembangan Bahasa Indonesia Pada Era Teknologi Informasi dan Komunikasi. http://gramatika. kemdikbud.go.id/index.php/gram- 
atika/article/download/30/17/.

Allan, K. (2001). Natural Language Semantics. Oxford: Blackwell Publishers Ltd.

Armalita, R., Helmi, A.F. (2018). Iri di Situs Jejaring Sosial:Studi tentang Teori Deservingness. Jurnal Psikologi, 45(3), 218-230. https://jurnal.ugm. ac.id/jpsi/article/view/33313.

Arofa, I.Z., Hudainah, \& Zulfiana, U. (2018). Pengaruh Perilaku Bullying terhadap Empati Ditinjau dari Tipe Sekolah. Jurnal Ilmiah Psikologi Terapan, 6(1), 74-92. http://ejournal. umm.ac.id/index.php/jipt/article/ view/5435.

Aune, N.M. (2009). Cyberbullying. Thesis. The Graduate School University of Wisconsin-Stout. http://www2. uwstout.edu/content/lib / thesis/2009/2009aunen.pdf (diakses tanggal 8 Juli 2019).

Dwiyanti, F. (2014). Pelecehan Seksual pada Perempuan di Tempat Kerja (Studi Kasus Kantor Satpol PP Provinsi DKI Jakarta). Jurnal Kriminologi Indonesia, 10(1), 29-36. http:// journal.ui.ac.id/index.php/jki/article/viewFile/7515/3817.

Gonzales, R. H. (2014). Social Media as A Channel and Its Implications on Cyber Bullying. Makalah disajikan pada DLSU Research Congress 2014, De La Salle University, Manila, Filipina, pp. 1-7. https://docplayer. net/22587680-Social-media-as-achannel-and-its-implications-on-cyber-bullying.html.

Hidajat (2015). Dampak Media Sosial dalam Cyber Bullying. ComTech, vol. 6(1), 72-81. https://journal.binus. ac.id/index.php/comtech/article/ view/2289/1708.

Ivena. (2019). "Benarkah Penyedap Rasa (MSG) Bisa Bikin Otak Jadi 'Lemot'?" https://hellosehat.com/ hidup-sehat/fakta-unik/benarkahpenyedap-rasa-msg-bisa-bikin-otakjadi-lemot/.

Kraft, E.M. Wang, J. (2009). Effective of Cyber bullying Prevention Strategies: A Study on Students' Perspectives. International of Cyber Criminology, 3(2), 514-535. https://www.cybercrimejournal.com/kraftandwangdec2009.htm.

Lestari, W. (2015). Peran Orang Tua dalam Pendidikan Seks pada Remaja. Magister Psikologi Universitas Muhammadiyah Surakarta. http:// eprints.ums.ac.id/41910/25/NASKAH\%20PUBLIKASI.pdf.

Li, Q. (2007). Bullying in The New Playground: Research Into Cyberbullying and Cyber Victimisation. Australasian Journal of Educational Technology, 23(4), 435-454. https://pdfs.semanticscholar.org/4903/48dcd182d 2f3e9d59e5fa375f2aeb6482343.pdf

Maya, N. (2015). Fenomena Cyberbullying di Kalangan Pelajar. JISIP: Jurnal Ilmu Sosial dan Ilmu Politik, 4(3), 443450. https://publikasi.unitri.ac.id/ index.php / fisip/article / view/125/160.

Modecki, K.L. (2014). Bullying Prevalence Across Context: A Meta-analysis Measuring Cyber and Traditional Bullying. Journal of Adolescnet Health, 55(5), 602-611. https://doi. org / $10.1016 / \mathrm{j} . \mathrm{j}$ a d o health.2014.06.007. 
Notar, C.E., Padgett, S. \& Roden, J. (2013). Cyberbullying: A Review of The Literature. Universal Journal of Educational Research, 1(1), 1-9. http: / /www.hrpub.org/download/201306/ujer.2013.010101.pdf.

O'Dea, B., Campbell, A.J. (2012). Online Social Networking and The Experience of Cyber-Bullying. Studies in Health Technology and Informatics, 181, 212-217. http://ebooks.iospress.nl/publication/22074.

Pratiwi, M.D. (2011). Faktor-Faktor yang Mempengaruhi Cyberbullying pada Remaja. Makalah disajikan pada seminar dan lokakarya APSIFOR Indonesia, Semarang, Indonesia. https: / / www.scribd.com / doc/106227383/Faktor-FaktorYang-Mempengaruhi-Cyberbullying.

Rachmatan, R., Rayyan. (2017). Harga Diri dan Perundungan Siber pada Remaja. INSAN Jurnal Psikologi dan Kesehatan Mental, 2(2), 111-117. DOI: http://dx.doi.org/10.20473/ jpkm.V2I22017.120-126.

Rahayu, A.P. (2015). Menumbuhkan Bahasa Indonesia yang Baik dan Benar dalam Pendidikan dan Pengajaran. Jurnal Paradigma, 2(1). http://ejournal.kopertais4.or.id/mataraman/index.php/paradigma/article/ view/886.

Ratnasari, R.F. (2016). Pentingnya Pendidikan Seks Untuk Anak Usia Dini. Tarbawi Khatulistiwa, 2(2), 55-59. http://openjurnal.unmuhpnk.ac. $\mathrm{id} /$ index.php/TaK/article/download/251/197.
Rifauddin, M. (2016). Fenomena Cyberbullying Pada Remaja. Jurnal Ilmu Perpustakaan, Informasi, dan Kearsipan Khizanah Al-Hikmah, 4(1), 35-44. http://journal.uin-alauddin.ac.id/ index.php/khizanah-al-hikmah/article/viewFile/1068/1030.

Rohman, F. (2016). Analisis Meningkatnya kejahatan Cyberbullying dan Hate Speech Menggunakan Berbagai Media Sosial dan Metode Pencegahannya. Makalah disajikan pada Seminar nasional Ilmu Pengetahuan dan Teknologi Komputer Nusa Mandiri 2016, STMIK Nusa Mandiri, Jakarta, Indonesia, pp. 383-388. https://konferensi.nusamandiri. ac.id/proceeding/index.php/ sniptek/article/view/124.

Roqib, M. (2008). Pendidikan Seks Pada Anak Usia Dini. INSANIA, 3(2), 271-286. http://ejournal.iainpurwokerto.ac.id/index.php/insania/ article/view/298.

Saaed, J.I. (2003). Semantics -2nd Ed. Oxford: Blackwell Publishers Ltd.

Sartana., Afriyeni, N. (2017). Perundungan Maya (Cyber Bullyng) pada Remaja Awal. Jurnal Psikologi Insight, 1(1), 25-39. http://ejournal. upi.edu/index.php/insight/article/ download/8442/5299.

Satalina, D. (2014). Kecenderungan Perilaku Cyberbullying Ditinjau dari Tipe Kepribadian Ekstrovert dan Introvert. Jurnal Ilmiah Psikologi Terapan, 2(2), 294-310. http://ejournal. umm.ac.id/index.php/jipt/article/ view/2003. 
Utami, Y. C. (2013). Cyberbullying di Kalangan Remaja. Skripsi. FISIP Airlangga. http://journal.unair.ac.id/ download-fullpapers-kmnts73d7a00d3dfull.pdf. (diakses tanggal 11 Juni 2018).

Utami, A.S.F., Baiti, N. (2018). Pengaruh Media Sosial Terhadap Perilaku $C y$ ber Bullying Pada Kalangan Remaja. Cakrawala, 18(2), 257-262. https:// ejournal.bsi.ac.id/ejurnal/index. $\mathrm{php} /$ cakrawala/article/view/3680.
Willard, N. 2007. "Cyberbullying and Cyberthreats: Effectively Managing Internet Use Risks in Schools". Center for Safe and Responsible Use of the Internet. https://www.cforks. org/Downloads/cyber_bullying.pdf (diakses tanggal 6 Juni 2018).

World Internet Users Statistics and 2018 World Population Stats. https:// www.internetworldstats.com/stats. htm (diakses tanggal 30 Mei 2018). 